\title{
THE EFFECTIVENESS OF AWIG-AWIG AS A STRATEGY TO PROTECT DMCA GILI SULAT AND GILI LAWANG
}

Fitriah Kartini ${ }^{1}$

${ }^{1}$ Sekolah Tinggi IImu Administrasi Mataram

\section{Info Artikel}

Sejarah Artikel:

Diterima: 9 Maret 2019

Disetujui: 29 Maret 2019

Dipublikasikan: 7 April

2019

\begin{abstract}
Abstrak
Studi ini dilakukan di Taman Wisata Perairan Gili Sulat dan Gili Lawang yang berlokasi di Desa Sambelia, Kabupaten Lombok Timur, NTB. Taman Wisata Perairan Glli Sulat dan Gili Lawang merupakan salah satu Kawasan Konservasi Laut Daerah yang diinisiasi oleh Proyek Co-Fish Kementerian Kelautan dan Perikanan Indonesia pada tahun 2004 sebagai bagian dari manajemen partisipatif di kawasan pesisir. Selain menerapkan peraturan pemerintah daerah mengenai pengelolaan kawasan konservasi perairan daerah berdasarkan zonasi, taman wisata perairan Gili Sulat dan Gili Lawang menggunakan awig-awig yang mengatur tentang tata cara dan denda yang diterapkan kepada nelayan jika melanggar kesepakatan yang telah disetujui. Hasil penelitian menunjukkan bahwa terdapat 2 peraturan yang diterapkan di KKLD Gili Sulat dan Gili Lawang, yaitu peraturan pemerintah dan awig-awig. Peraturan pemerintah diberlakukan untuk wilayah KKLD, sementara itu awig-awig diberlakukan sebagai alat hukum untuk mengontrol sikap dan perilaku orang-orang yang berhubungan dengan KKLD Gili Sulat dan Gili Lawang. Awig-awig Gili Sulat dan Gili Lawang tidak efektif dalam penerapannya untuk menurunkan angka perusakan biota laut saat nelayan mengambil tangkapannya karena menimbulkan konflik diantara lapisan sosial masyarakat Desa Sugian. Hal ini dikarenakan persepsi terhadap penentuan Gili Sulat dan Gili Lawang sebagai Taman Wisata Perairan yang beragam.
\end{abstract}

\section{THE EFFECTIVENESS OF AWIG-AWIG AS A STRATEGY TO} PROTECT DMCA GILI SULAT AND GILI LAWANG

\section{Keywords:}

MPA, customary

law

\section{Abstract}

This study was carried out in the District Marine Conservation Area (DMCA) of Gili Sulat and Gili Lawang, East Lombok. DMCA of Gili Sulat and Gili Lawang, administratively part of Sugian Village in Sambelia sub-dictrict, have established by Co-Fish Project of Marine Affairs and Fisheries Ministry of Indonesia in 2004 as part of participative management sustainability to coastal resources. The aim of establishing DMCA is to decrease destructive fishing activities such as bombing and poisoning that has been practices for long time. In this study, data were collected through semi structure questionnaires, personal interview, participant observation, document reviews, and life history. Discussions were held with the fishermen in Sugian Village, fisheries management committee of DMCA, local communities who living in Sugian Village and government in village, local and regional level. In order to 
analyze the findings, an analyzing of legal and institutional arrangements is used combining with the theories of legal pluralism and property rights.

The study revealed that there are two laws coexist in DMCA as state laws and customary laws called awig-awig. State laws are covered legal status of DMCA as property of state where local government has authority to manage it. Meanwhile, customary laws are more to control people behaviors towards DMCA. Moreover, a fisheries management committee (KPPL) has formed by government to enforce day-to-day awig-awig practices towards DMCA and has its authority to invoke sanctions for rule breaking. Because of this, several problems arose in Sugian Village concerning to DMCA. This required better management of coastal resources where planning should be come from and involve grass root level. Finally, the study revealed that management of DMCA should be reinforced to all parties particularly on communities' level, so that the problem foci can be clear for all

( 2018 Sekolah Tinggi llmu Administrasi Mataram

Alamat korespondensi:

fitrikartini@gmail.com

\section{INTRODUCTION}

Indonesia consists of 17,000 islands in which less than 6,000 are inhabitants. Geographically, Indonesia has $82,000 \mathrm{~km}$ coastline. Its seas are considered to have one of the greatest marine biodiversity in the world. However, it is also recognize as host to some natural disasters, such as earthquakes, floods, tsunamis, and explosive volcanoes. As coastal nation, Indonesia deals with broader issues on climates, ecosystems, community structures, and diverse socio-cultural groups.

The destructive fishing activities indicate that $60 \%$ of coral reefs are damage and at high risk. Nowadays, Marine Protected Area (MPA) has become better implemented to protect the coastal resource from human exploitation. According to Murdiyanto (2003:57), the MPA can be varied in size, have diverse goals either only temporary or long-term. Indonesia itself has established nine Marine National Parks with a total area of $41,129 \mathrm{~km} 2$ or $11.5 \%$ of the total nationally protected areas (Clifton, 2003:1). The first proposal to establish MPAs was in 1973 (Alder et.al, 1994:63) and started the first MPA in 1983 through Forestry Department (PHPA) (ibid: 180).

West Nusa Tenggara, one of provinces in the eastern part of Indonesia consists of two main islands, Lombok and Sumbawa. It is about $70 \mathrm{~km}$ across and a total area of about $4,725 \mathrm{~km}^{2}$ (1,825 sq mi). Lombok Island is divided into four areas, West Lombok, North Lombok, Central Lombok and East Lombok. In 2005, East Lombok has been chosen as the only one district in Indonesia to implement model of code of conduct for 
responsible fisheries (CCRF) followed by the highest honors from Indonesian Government, Adi Bakti Mina Bahari, as the best area of marine and fisheries development in 2006. CCRF code is used to give an authority to state to involve people engaged in fisheries management, their fish catches responsibly.

New paradigms for participatory management by communities become widely implemented to all coastal zone areas in East Lombok. The Directorate General of Capture Fisheries of Marine Affairs and Fisheries Ministry started Co-Fish (The Coastal Community Development and Fisheries Management) Project in 1998 and completed in 2004. In 2001, the project established six Coastal Zone Management Areas (Kawasan Pengelolaan/KP) in East Lombok coastline to protect the coastal from destructive fishing activities then it is decreased to only 4 (four) Coastal Zone Management Areas (KPPL).

Enforcement the idea of awig-awig or local rules in four KP areas has decreased the number of destructive fishing activities significantly. The four areas are located in (1) Sambelia, (2) Priggabaya, (3) Labuhan Haji and (4) Sakra Timur. The awig-awig is formed to boundaries fishing activities, protect coastline area such as mangroves, sand beaches and sea corals), also as institutional and financial engagement collected from fine of rules violation.

\section{Research objectives and research questions}

The objectives of this research are (1) To gain better understanding of the customary laws (awig-awig) in DMCA of Gili Sulat and Gili Lawang; (2) To understand the rules and regulations for use of DMCA of Gili Sulat and Gili Lawang; and (3) To understand different interest groups using the DMCA of Gili Sulat and Gili lawang in the actual practices.

This research has several raised questions: (1) What are the new rules and regulations established for the District Marine Conservation Area of Gili Sulat and Gili Lawang?; (2) What are the implications of these new rules for the livelihoods of primary users, particularly fishers?; (3) How effective is the participatory approach using the idea of awig awig?

This study was carried out in Sugian Village, Sambelia Sub-district, East Lombok, West Nusa Tenggara Province, Indonesia. The focus of this research is District Marine 
Conservation Area (DMCA), which was set up in Gili Sulat and Gili Lawang in 2004 and administratively belongs to Sugian Village.

\section{RESEARCH METHODS}

The case study has chosen as a research strategy. According to Punch (2005:320), the basic idea is one case (or perhaps a small number of cases) will be studied in detail, using whatever methods seem appropriate.

While there may be a variety of specific purposes and research questions, the general objective is to develop as full an understanding of that case as possible. The unit of analysis in this research is institutions, individuals and groups practices. According to Uphoff (1986:9), institutions are complexes of norms and behaviors over time by serving collectively valued purposes. Institutions mentioned are institutions as laws and organizations.

Primary data is collected thorough several methods such as participant observation, interviews (snowball methods in semi structured and unstructured questionnaires). Meanwhile, secondary data is collected from Marine and Fisheries Affairs in Province and District level, Village Government office, and Forestry unit (BPDAS/Watershed Office) in Province level in the form of project reports, regulations, and rules, and project report of WCS (The Wildlife Conservation Society) Indonesia which are reliable and validity with the topic.

\section{RESULTS}

a. How and why Awig-awig of Gili Sulat and Gili Lawang emerge

Awig-awig in local terms means customary laws. It comes from Balinese terms, which had colonialized Lombok in the seventeenth century. Awig-awig itself is in unwritten form and has to obey by community in particular area. It involves particular stakeholder in the making process through consensus called musyawarah. According to Koesno 1969 cited in Slaats and Portier, (1992:1), musyawarah is used as the general term to refer to such processes of formal deliberations and decision-making embodying the notion of Indonesian traditional democracy. The process of developing awig-awig DMCA of Gili Sulat and Gili Lawang has been going through consensus of element parties in developing marine conservation area.

Awig-awig developed in the sense that in Lombok Island, participative or collaborative management can only be carried out using awig-awig as its management tool (Bachtiar, 2005). The form of awig-awig in East Lombok coastal line has introduce by 
Co-Fish project around co-management system that involve both local government and the local community represent by KPPL (Fisheries Management Committee) to reduce destructive fishing activities. The awig-awig is compilation of local or traditional rules that enforce users towards DMCA.

b. How does awig-awig of Gili Sulat and Gili Lawang manage the marine and coastal resources?

The awig-awig of Gili Sulat and Gili Lawang consists of rules in prohibited area and activities can be done surrounding the DMCA. It is also declared the restrictions of gear type use by fishers to catch fish. Rules according to Ruddle (1996) give substances and structure to property rights by defining how a right is to be exercised through specification required, permitted, and forbidden acts in exercising the authority provided by the right. Based on state law and awig-awig, the limitation of activities more or less divided into three zones system; core or no-take zone, buffer zone, and exploitation zone that each zoning has strict rules. In the no-take zone, none activities can be done except for research and education purposes. Buffer zone is allowed limited activities by permission of KPPL. The exploitation zone seems as an area in which exploitation activities can be done, though, limited gear types are mentioned.

Further, the limitation to use particular fishing equipment's has created conflict between KPPL (the committee) and fishers as well. Likewise, the interpretation to rules prohibited and permitted activities can be done on the DMCA is various among fisher, village government, the KPPL and on the government level Institutional aspects

The existences of DMCA Gili Sulat and Gili Lawang has been involved several actors in planning activities. Definition of institutional by Uphoff (1993) is complexes of norms and behaviors that persist over time by serving collectively purposes while organization is as structures of recognized and accepted roles. He mentioned three categories are commonly recognized: 1) organizations that are not institutions, 2) institutions that are not organizations and 3) organizations that are institutions or vice versa. Although it is quite complex of definitions, but what I am going to explain in the next section is about organization roles matters in which several organizations identified were engaged on decision-making process of DMCA and establishment of awig-awig in DMCA. For each organization engaged in DMCA will be described as follows: 


\section{Institutional arrangements at the national and regional level}

There were several organizations at national and regional level played their role mostly in decision-making and planning management process to develop Gili Sulat and Gili Lawang as protected area even in the implementation period. The decision-making situated on the top level of government organ (Marine Affairs and Fisheries Ministry) and mandated Co-Fish to implement the result of REA (Research and Ecological Assessment) which had done before. The Co-Fish then coordinate with YSLPP (Resources and Environmental for Sustainable Development Foundation) to implement and coordinate the planning at the regional and local level. YSLPP together with CoFish then coordinated the program to Marine Affairs and Fisheries Agency at regional (provincial level) and local (district level) for development plans. Hence, the coordination going further to other organizations such as BKSDA (Natural Resources Conservation) and BPDAS (Watershed Management) to harmonize the program between DMCA by Marine Affairs and Fisheries (DKP) and mangroves rehabilitation by Forestry Department.

\section{Institutional characteristics of awig-awig}

Ostrom (1990:90) design is used to identify awig-awig as institution whether the institutions in sustaining CPRs are appropriate to the DMCA. The design indicators are: (1) clearly defined boundaries, (2) congruence between appropriation and provision rules and local conditions, (3) collective-choice arrangements, (4) monitoring, (5) graduted sanctions, (6) conflict-resolution mechanism, (7) minimal recognition of rights to organize, (8) nested enterprises. Explanation of each design will describe as follow:

1. Clearly defined boundaries

Individuals or households who have rights to withdraw resource units from the CPR must be clearly defined, as must the boundaries of the CPR itself.

Boundaries mentioned in awig-awig are the area of Gili Sulat and Gili Lawang that belongs to Sugian Village. There are four sub villages in Sugian; Sugian, Dadap,

The DMCA are divided into three zones; no-take/core zone, buffer zone, and exploitation zone. Each zone has different rules strict to forbidden and prohibited activities fishers can catch particularly gear types and fish species restrictions. No-take zone is closed to human activities except for research and study. Meanwhile, buffer zone is the area where several activities can be done with permission of KPPL (Fisheries Management Committee). 
2. Congruence between appropriation and provision rules and local conditions Appropriation rules restricting time, place, technology, and/or quantity of resource units are related to local conditions and to provision rules requiring labor, materials, and/or money.

Besides zoning system, awig-awig also limiting fishing equipment used for catching fish. The fishing equipment are limited to fishing rod and net for small-scale use. It is not allowed to use grill net, compressor (as tool for dive fishing), and anchoring the boats.

Furthermore, there are several types of fishes cannot be caught in the water area of Gili Sulat and Gili Lawang such as decorative fish, dolphin, sea cow and tortoise. All kind of destructive fishing practices such as poison and bomb, electric tools, flash light usually use at night fishing and arrow also harpooning are highly prohibited even though this practices had done for many times in the past by fishermen.

3. Collective choice arrangements

Most of individuals affected by the operational rules can participate in modifying the operational rules

The collective-choice arrangements are closed to participation of individual in operational rules. The process establishment of awigawig is described on Figure 8 . The process of awig-awig involved only local communities representatives, village government, local leaders, DKP (Marine Affairs and Fisheries Agency), local government, police officers, and representatives of neighboring villages and KPPL (fisheries management committee) from Kawasan (coastal zone management). Meanwhile, from interviews conducted during fieldwork, not one fisher has been involved in decision making.

4. Monitoring Monitors, who actively audit CPR conditions and appropriator behavior, are accountable to the appropriators or are the appropriators to enforce day-to-day awig-awig practices, Marines and Fisheries Agency (DKP) set up a monitoring committee called KPPL. The management committee (KPPL) is a local community organization with membership from various backgrounds such as fishers, religious leader, community leaders, local guards, entrepreneurs, and village government. Considering historical line of its establishment, KPPL in the village level consists of six members from diverse backgrounds. In fact, male dominates them and only five members were actively doing the monitoring activities as KPPL. Local leaders and community representatives were elected KPPL members. The determination KPPL village members by local leader, later created conflict among members and 
communities as well. As I found that KPPL is not representatives of primary group of users, most of them are local community that is not fishers.

\section{Graduated sanctions}

Appropriators who violate operational rules are likely to be assessed by graduated sanctions (depending on the seriousness and context of the offense) by other appropriators, by officials accountable to these appropriators, or by both. Ruddle (1996) mentioned four principal types of sanctions in Asia- Pacific region: social, economic, physical punishment, and supernatural. Social sanction is including ridicule, shaming, ostracism, and banishment. Economic sanction is including monetary and inkind fines destruction of gear and forced labor. Meanwhile, physical punishment is more or less uncommon penalty like death.

The supernatural sanction means all pervasive throughout the region, and fear of them reinforces the other types of sanctions. Further, Awig-awig of Gili Sulat, Gili Lawang is clearly mentioned step of sanction for violators on economic rather than bring them to the court processes.

The procedure of giving sanction is followed several steps differently for each zones by KPPL. The committee has authority to give fined to violators directly on the sea first then bring to legal authority further for the third times of violations. Several rules of violations and sanctions are followed:

1. Violation against provisions in the awig-awig is sanctioned and fine as follow:

a. Entering clear the core zone unreasonably hence will be given sanction in the form of :

- First violation will be given a warning verbally while at the same time to socialize and give understanding and study about area of conservation management of the MPA

- If the perpetrator did the second violation hence fined maximum of Rp. 1.500 .000 directly take into effect for him

- If the perpetrator was found again for the third violation hence catching appliance confiscated of the perpetrator are seized and directly delivered to the authority with legal process with punishment and to be fined equal to Rp. 2.500 .000

b. Conducting fish catching with bombing, potassium/aenesthetic, electric current or a kind at the core zone, buffer zone and exploiting zone, will be given the following sanction:

- If the appropriator was found do the first bombing, the fined payment is approximately Rp. 5.000 .000 besides send to court. 
- If the appropriator was found for the second time bombing, the fined payment is approximately Rp. 10.000 .000 and sends to the court.

- If the appropriator was found for the third time bombing, they will send directly to the court.

c. Violation in the form of bombing, poisoning, and use of any kinds of dangerous substances will proceeded to the court directly.

d. The fined payment above are not applicable to those who doing night fishing by arrow and flash light. The KPPL has the authority to give the sanctions directly on the sea.

2. The sanctions will be fined to whom cutting, collecting, and peeling the mangroves trees in the protected areas. The fined payment as follow:

1) First warning to violators with his evidences should pay approximately Rp. 500.000 per tree fined also replanting the trees in the area.

2) Second violations will be fined Rp. 1.000 .000 per tree also replanting the trees in the area.

3) Third violations will send directly to the court.

4) For picking up the mangrove, fruits are possible with permission, which is paying retribution to KPPL.

5) Taking, ruining and collecting coral reefs will be fined as below:

a. First warning and fined payment up to Rp. 1.000 .000

b. Second violations will pay Rp. 2.000 .000

c. Third violations will send directly to court.

6) Catching decorative fishes, dolphins, turtles and mermaids on each zoning areas will be sanctioned as follow:

a. First warning together with fined of Rp. 500.000 will be given to violators who catching decorative fishes such as mermaids, dolphins and turtles. They have to release the fishes directly to the sea.

b. Second time violation with approximately Rp. 1.000 .000 fined per fish

c. Third violations will be sent to court.

\section{Conflict resolution mechanism}

Appropriators and their officials have rapid access to low-cost, local arenas to resolve conflicts among appropriators or between appropriators and officials.

In the awig-awig of Gili Sulat and Gili Lawang, there are rights and obligations stated for fishers as primary users. The rights are determining access to resources in 
particular zones. The conflict in Gili Sulat and Gili Lawang can be seen from two sides; internal and management mechanism. The conflict is situated between KPPL and fishers as well. KPPL Sugian has authority from government to do day-to-day practices and enforce awig-awig to its users. On one hand, users claimed that KPPL want to exclude them from DMCA as place of livelihood sources. Limitation of access and gear type used mostly used by fishers is sources of conflict. From fishers' point of view, Gili Lawang and Gili Sulat are place of alternative source to catch fishes, fuel wood, and other income sources. On the other hand, the water area is open fishing ground for them. Although no one can give evidences but corruption issues has brought negative perception to KPPL. Meanwhile, from KPPL point of view, they have rights to enforce people to obey awig-awig because their authority from government to do day-to-day practices. The peak conflict between fishers and KPPL occurred in the end of October when group of fishers protest against KPPL. They were asking to reshuffle KPPL members and doing election to elect KPPL members by them not by government or representatives. They considered that awig-awig is not rules made by them but by KPPL who are not fishers.

\section{Minimal recognition of rights to organize}

The rights of appropriators to devise their own institutions are not challenged by external governmental authorities. Ostrom explained that appropriators frequently devise their own rules without creating formal governmental jurisdictions. Fishers itself defining rules toward fishing ground and kind of equipment can be used. The rules should be legitimized by government officials in whom the fishers are able to enforce the rules by themselves. Referring to historical establishment of awig-awig for Gili Sulat and Gili Lawang, the awig-awig has developed by communities where DMCA located. Although the project was collaborated with YSLPP (local NGO) to facilitate compilation of awig-awig through participative methods such as resources mapping, zoning systems, sanctions, and management planning, however, the process cannot be seen as participative since it was not involved group of fishers as primary users. The processes of awig-awig compilation, local community representatives, and official staffs of government institution were involved in the process of establishing rules. The existences of government institution might be more powerful to impose such rules and regulations towards DMCA to local.

In addition, awig-awig at the end was legitimated by government institutions, as means local rules have to obey by local people and outsiders to DMCA. On the way to do day- 
to-day practices, KPPL Sugian has authority from government to enforce rules in awigawig to users as well. From government side, KPPL is part of community representatives that elected through democratic ways. KPPL in fact, as important element of participative management institution develop by Co-Fish project to assist government in coastal zone management programs. The existence of KPPL is legitimated by DKP Decree (Marine Affairs and Fisheries Agency). For that reasons, community in Sugian Village view KPPL is as the same as government by their enforcement of awig-awig to exclude fishers from DMCA management (pers. com., 2007).

\section{Nested enterprises}

Appropriation, provision, monitoring, enforcement, conflict resolution, and governance activities are organized in multiple layers of nested enterprises.

The awig-awig of Gili Sulat and Gili Lawang has its legitimation from Sub-district government of Sambelia as awig-awig of Sugian Village where DMCA located. Due to its historical establishment, awig-awig has involved participants from diverse background to bring together their interests to DMCA and actualized in awig-awig rules. Since awig-awig has linkages to many parties, so that the existences of awig-awig itself has enforced those who has interests to DMCA both insiders and outsiders. However, the monitoring process was responsibility by KPPL only in practices.

\section{Conclusion}

There are two kinds of law existed in DMCA, state laws and customary laws called awig-awig, where state laws is the highest legal order. State laws contain claims from government to resources as property of state and government has authority to manage it. Meanwhile, the existences of awig-awig as customary laws recognized as management tool to involved local community in participative management has failed. Although both state laws and customary laws include sanctions of violations, however, it cannot be classified into conflict resolution. Awig-awig receives legitimacy from local and central government but awig-awig is still challenged by fishers as the most users. The contents of awig-awig does not coincide with the way of fishers define their problems.

The existing such laws and local regulations toward DMCA provide an insufficient legal basis for control of coastal and marine management systems. Autonomy law or known as decentralization law cannot be claimed that central government really cedes its 
authority to local level. In Indonesian legal systems, there is no authority of village level to manage seawater. The boundaries of villages only located inland. It is contradictive with the sense of belonging and owning by local particularly fishers to resources. It caused such conflict over the fishing rules and areas on DMCA. Meanwhile, management systems approach is not very traditional management because government has set up integrated management team/KKLD team to manage DMCA where most of them are government staffs.

Meanwhile, determination of customary law/awig-awig in DMCA as management tools is lack of recognition by local communities, though, users both local fishers and other fisher groups towards DMCA should obey it. Nevertheless, the appearance of awigawig in DMCA has contributed to the conflict between resources users and KPPL particularly on gear types and boundaries issues.

As explaining on robust management by Ostrom's designs, I would argue that awigawig of Gili Sulat and Gili Lawang is weak. The weakness of awig-awig in DMCA is located on the process of establishment. Awig-awig contents are designate to fishers as primary users, but fishers itself did not involve in establishment process. Moreover, awig-awig that claimed by government as product of local, is unable to handle of conflicts between fishers and KPPL (Fisheries Management Committee). The characteristics of awig-awig as identity of community have strong considering as product of rules imposed by government.

In addition, institutional aspect of DMCA mostly played on the highest level of decisionmaking. Followed by Uphoff (1986), what is called a community may provide no substantial social basis for collective action. Local meaning is different from perspective of government and Sugian people. In my point of view, government might classify local based upon geographical label such as residential unit, however, community itself see themselves as set of persons having some common interest. The difference meaning of local, latter is as root of conflict particulary in participatory management model.

\section{References}

Alder J., Sloan N. A., and Uktolseya H., 1994. Advances in Marine Protected Area Management in Indonesia, 1988-1993. Ocean and Coastal Management No. 25. pp. 63-75.

Bachtiar I., 2005. Integrating formal and customary approaches to responsible fisheries: a case study of District Fisheries Services in Nusa Tenggara Barat Province, Lombok, Indonesia. Fish for People Vol. 3 No 2. pp. 38-47. 
Clifton J., 2003. Prospects for co-management in Indonesia's marine protected areas. Marine Policy 27. pp. 389-395.

Co-Fish 2003. Co-Fish Programs in East Lombok. Cooperation with YSLPP. A Project report.

Co-Fish, 2004. Inventarisasi dan Penilaian Potensi Kawasan Konservasi Laut Baru di Provinsi Nusa Tenggara Barat. Bab IV-VIII.

Murdiyanto B., 2003. Mengenal, Memelihara Dan Melestarikan Ekosistem Bakau. Proyek Pembangunan Masyarakat Pantai dan Pengelolaan Sumber Daya Perikanan. Direktorat Jenderal Perikanan Tangkap-DKP. pp 57-60.

Ostrom E., 1990. Governing the commons. The evolution of institutions for collective action. Cambridge University Press.

Profil Desa, 2006. Profil Desa Sugian. Kantor Pemerintah Desa Sugian, Lombok Timur, NTB.

Punch K. F., 2005. Introduction to social research. Quantitative and qualitative approaches. Second edition. Sage Publications. London. 320p.

Rencana Pengelolaan dan Zonasi Taman Wisata Perairan Gili Sulat dan Gili Lawang Tahun 2016-2036., Dinas Kelautan dan Perikanan Provinsi Nusa tenggara Barat, 2016. Ruddle K., 1996. Traditional Marine Resources management Systems in the AsiaPacific Region: Design Principles and Policy Options. FAO Paper No. 13 in Workshop on Integrated Reef Resources Management in the Maldives-Bay of Bengal Program. Editors: Donna J. Nickerson, and Maizan Hassan Maniku.

Satria A., Matsuda Y., Sano M., 2006. Questioning community based coral reef management systems: case study of awig-awig in Gili Indah, Indonesia. Environment, Development and Sustainability 8.pp 99-118.

Satria A., Matsuda Y. and Sano M., 2006. Politics of marine conservation area in Indonesia: from a centralised to a decentralised system. Int. J. Environment and Sustainable Development, Vol. 5, No. 3. pp. 240-261

Slaats H. and Portier K., 1992. Traditional decision-making and law Institution and processes in an Indonesian context. Gadjah Mada University Press.

Uphoff N., 1986. Local Institutional Development: An Analytical Sourcebook With Cases. Kumarian Press.

Uphoff N. 1993. Grassroots Organizations and NGOs in Rural Development: Opportunities with Diminishing States and Expanding Markets. World Development, Vol. 21, No. 4, pp. 607-622. 
Wildlife Conservation Society-Indonesia Program, 2014. Laporan Kajian Aspek SosialEkonomi Dalam Pengelolaan Kawasan Koservasi Perairan Daerah Gili Sulat-Gili Lawang, Kabupaten Lombok Timur. Bogor, Indonesia.

Internet sources

Retrieved from:

http://www.oceansatlas.org/unatlas_gifs/offsiteframe.jsp?url=http\%3A\%2F\%2Fwww.fa o.org\%2Fdocrep\%2F003\%2Fx9066e\%2Fx9066e00.htm\&ctn=13255\&kot=books, on 18 September 2006

http://www.cofish.net/indonesia/cofishid.php?m=2\&t=1\&v=1\&id=107, on 8 September 2006

http://www.weltrekordreise.ch/flags-maps/indonesia-lombok-mapphoto.jpg, on 3 June 2007

http://www.lomboktimur.go.id/main/index.php, on 1 May 2007.

List of Regulations

National Laws

Basic Constitution of 1945

Law No. 69/1958 concerning Regional establishment at Provincial level of Bali, West Nusa Tenggara, and East Nusa Tenggara

Law No. 9/1985 concerning Fisheries

Law No. 5/1990 concerning Conservation of Biological Natural Resources and Ecosystems

Law No. 9/1990 concerning Tourism

Law No. 24/1992 concerning spatial use management

Law No. 23/1997 concerning Environmental management

Law No. 22/1999 concerning Regional Governance

Government Regulations

Government Regulation (PP) No. 6/1988 concerning Regional Vertical Institution Coordination

Government Regulation (PP) No. 68/1998 concerning Protected Areas

Government Regulation (PP) No. 27/1999 concerning Environmental Impact Assessment 
Government Regulation (PP) No. 25/2000 concerning Government Authority and the Provincial Authority as an Autonomous Region

Government Regulation (PP) No. 20/2001 concerning Fostering and Supervision of Local Governance

Presidential Decrees

Presidential Decree No. 32/1990 concerning Protected Area

Presidential Decree No. 44/1999 concerning Technical Arrangement of Acts, Government Regulations and President Regulations Planning Form

Presidential Decree No. 74/2001 concerning Monitoring Regional Government Arrangement

District Regulations

District Regulation of East Lombok No. 9 Year 2006 concerning Participatory management fisheries resources

District Regulation of East Lombok No. 10 Year 2006 concerning District Conservation Area Management

\section{Bupati's Decrees}

Bupati Decree No. 188.45/452/KP/2004 concerning Establishment Gili Sulat and Gili Lawang as District Marine Conservation Area

Bupati Decree No. 188.45/385/KP/2006 concerning Integrating Management Team of DMCA

Ministry of Marine and Fishery Decree concerning Management and Zonation Planning Taman Wisata Perairan Gili Sulat dan Gili Lawang Year 2016-2036 Kawasan Konservasi Perairan, Pesisir dan Pulau-pulau Kecil Provinsi NTB 